\title{
PEGARUH IKLAN LAYANAN MASYARAKAT TERKAIT MASYARAKAT EKONOMI ASEAN DI YOUTUBE DAN CULTURAL INTELLIGENCE TERHADAP MINAT BERKARIER MAHASISWA UNTUK BEKERJA DI LUAR NEGERI
}

\author{
Sekar Dewanti Wiryaning Saputri ${ }^{1}$, Elke Alexandrina ${ }^{2}$ \\ LSPR Jakarta,

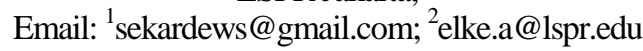

\begin{abstract}
ABSTRAK
Penelitian ini bertujuan untuk mengetahui pengaruh iklan layanan masyarakat terkait Masyarakat Ekonomi ASEAN di Youtube dan cultural intelligence terhadap minat berkarier mahasiswa untuk bekerja di luar negeri. Konsep yang digunakan adalah dimensi periklanan, cultural intelligence, dan minat. Metode penelitian yang digunakan adalah kuantitatif. Populasi penelitian ini adalah mahasiswa Universitas Trisakti Fakultas Ekonomi dan Bisnis. Data dalam penelitian ini diolah menggunakan Partial Least Square (PLS) dengan program aplikasi smartPLS 3.0. Dari hasil penelitian ini diketahui bahwa iklan tidak berpengaruh terhadap minat, cultural intelligence berpengaruh terhadap minat, sedangkan kontribusi dari iklan layanan masyarakat terkait Masyarakat Ekonomi ASEAN di Youtube dan Cultural Intelligence terhadap Minat berkarier mahasiswa untuk bekerja di luar negeri adalah sebesar 66\% dan 34\% sisanya dipengaruhi oleh faktor lain. Saran yang didapat dari hasil penelitian ini untuk penelitian serupa yang akan datang adalah penelitian faktor-faktor lain berupa efektivitas iklan, penggunaan animasi pada iklan atau penggunakan musik pada iklan.
\end{abstract}

Kata kunci: Masyarakat Ekonomi ASEAN, Iklan Layanan Masyarakat, Cultural Intelligence, Minat, Mahasiswa

\begin{abstract}
This study aims to determine the effect of public service annoucements related to the ASEAN Economic Community on Youtube and cultural intelligence towards interest of students to work abroad. The concepts used are the dimensions of advertising, cultural intelligence, and interest. The research method used is quantitative. The population of this study were Trisakti University faculty of Economics and Business. The data in this study were processed using Partial Least Square (PLS) with the SmartPLS 3.0 application program. From the results of this study noted that PSA has no effect on interest, cultural intelligence affects interest, while the contribution of public service annoucement related to the ASEAN Economic Community on Youtube and Cultural Intelligence towards student career interests to work abroad is $66 \%$ and the remaining $34 \%$ influenced by other factors. From this study, research of other factors in the form of advertising are possible for similar research to come.
\end{abstract}

Keywords: ASEAN Economic Community, Public Service Annoucement, Cultural Intelligence, Interest, College Students.

\section{PENDAHULUAN}

ASEAN Economic Community (AEC) atau di Indonesia lebih dikenal dengan sebutan Masyarakat Ekonomi ASEAN (MEA) merupakan sebuah bentuk persatuan di bidang ekonomi oleh negara anggota ASEAN (Indonesia, Malaysia, Singapura, Brunei Darussalam, Filipina, Thailand, Laos, Myanmar dan Vietnam). Tujuan didirikannya MEA adalah untuk menciptakan wilayah ASEAN yang aman dengan tingkat dinamika pembangunan yang lebih tinggi dan terintegrasi, pengentasan masyarakat ASEAN dari kemiskinan, serta pertumbuhan ekonomi untuk mencapai kemakmuran yang merata dan berkelanjutan. Untuk itu MEA memiliki empat karakteristik utama, yaitu pasar tunggal dan basis produksi, kawasan ekonomi yang berdaya saing tinggi, dan kawasan dengan pembangunan ekonomi yang merata, serta kawasan yang teritegrasi penuh dengan ekonomi global. ("Masyarakat Ekonomi ASEAN (MEA)", 2015, n.d, para. 1).

Pada KTT tahun 2006, MEA disepakati untuk diberlakukan lebih cepat lima tahun dari yang direncanakan, yaitu menjadi tahun 2015. Hasil dari kesepakatan itu menghasilkan deklarasi CEBU yang membuat keputusan bersama dari tahun ke tahun menjadi semakin nyata dan mencangkup berbagai komponen ekonomi lebih luas seperti barang, labor, modal investasi hingga jasa. (Dit. Kerja Sama Ekonomi ASEAN, 2015, p.10).

Karakteristik utama berdirinya MEA adalah menciptakan pasar bebas dan pemerataan ekonomi bagi semua negara anggota ASEAN. Pasar bebas sebagai poin pertama dalam karakteristik utama dibentuknya 
MEA menjadi topik yang menarik, dimana pembentukan pasar tunggal ini memiliki lima agenda utama yaitu aliran bebas barang, aliran bebas jasa, aliran bebas investasi, aliran modal yang lebih bebas, serta aliran bebas tenaga kerja terampil. Disamping itu, sebagaimana dijelaskan pada halaman situs Kementrian Luar Negeri Republik Indonesia (2015). Dari keenam agenda yang dimiliki pasar bebas, fokus penelitian ini terdapat pada Arus Bebas Lalu Lintas Tenaga Kerja terampil yang dijelaskan sebagai berikut:

Arus Bebas Lalu Lintas Tenaga Kerja Terampil Mengacu pada pengaturan liberalisasi jasa World Trade Organization (WTO) yaitu General Agreement on Tariffs and Trade (GATT), ASEAN berupaya untuk mendorong integrasi sektor jasa di kawasan. Melalui AFAS, proses liberalisasi ASEAN secara gradual memberikan kesempatan bagi tenaga kerja terampil yang telah disepakati oleh ASEAN untuk dapat berpindah dari satu negara ASEAN ke negara ASEAN lainnya tanpa mengalami hambatan. Untuk memfasilitasi perpindahan tenaga kerja tersebut, ASEAN telah menyepakati Mutual Recognition Arrangment (MRA) untuk penyetaraan kualifikasi tenaga kerja terampil yang telah disepakati di ASEAN. Terdapat delapan profesi yang tertuang dalam MRA yaitu insinyur, arsitek, tenaga kerja pariwisata, akuntan, dokter gigi, tenaga survei, praktisi medis dan perawat. ("Masyarakat Ekonomi ASEAN (MEA)", 2015, n.d, para. 5).

Pada penelitian ini ingin diketahui apakah mahasiswa sebagai salah satu kelompok yang memiliki potensi terbesar untuk berpartisipasi dalam MEA, tertarik untuk berkarier di negara anggota ASEAN. Untuk melihat tumbuhnya sebuah minat atau tidak, maka ingin diteliti faktor internal dan eksternal yang mampu mempengaruhi minat mahasasiwa. Pada penelitian ini, faktor internal yang digunakan untuk mengukur minat berkarier mahasiswa untuk bekerja di luar negeri adalah Cultural Intelligence. Cultural Intelligence atau kecerdasan kultural, dipahami sebagai sebuah kemampuan individu, tim ataupun perusahaan untuk berperilaku secara efektif dalam konteks antar budaya. (Dyne, 2017, p.2)

Individu yang memiliki Cultural Intelligence dianggap secara mendalam mengetahui proses interaksi sosial pada konteks antar budaya, memiliki pengetahuan umum budaya (norma, praktik dan peraturan dalam sebuah budaya), mempunyai keinginan yang tinggi untuk menerjemahkan informasi yang diperoleh untuk berinteraksi dan menangani pekerjaan, serta mampu berkomunikasi melalui verbal maupun non-verbal secara tepat. Dengan memiliki kemampuan tersebut, mahasiswa yang berminat untuk berkarier di negara asing dianggap mampu untuk beradaptasi dan berkomunikasi dengan tepat, baik dalam keseharian maupun dalam lingkungan bekerja. Maka dari itu Cultural Intelligence diperlukan bagi mahasiswa yang hendak bekerja di negara asing.

Faktor eksternal yang digunakan adalah Iklan Layanan Masyarakat di Youtube. Kala ini komputer merupakan sumber utama khlayak untuk mempelajari apa yang sedang terjadi di dunia, untuk mencari hiburan, untuk bergembira, untuk relaksasi, untuk melupakan masalah, untuk menghilangkan kesepian, untuk mengisi waktu atau sebagai sebuah kebiasaan. Sifat media yang paling penting bagi pengguna situssitus online adalah Kesiapan (dapat mengetahui sesuatu dengan segera) dan Stabilitas (dapat memperoleh berita kapan saja mereka inginkan adalah yang paling penting bagi pengguna situs-situs berita online.

Salah satu video yang menjadi video teratas saat melakukan pencarian dengan kata kunci "Masyarakat Ekonomi ASEAN" di Youtube adalah video dari Friedrich Ebert Stiftung yang merupakan hasil kerja sama dengan ASEAN Services Employees Trade Union Council (ASETUC) yang diunggah pada 16 Desember 2014. Sebuah video animasi yang kemudian di dubbing dengan informasi seputar MEA berdurasi empat 4 menit 32 detik tersebut berhasil ditonton sebanyak 31 ribu kali dengan 164 orang pengguna Youtube yang menyukai, 2 orang yang tidak menyukai dan 3 komentar pada halaman video.

Rumusan masalah pada penelitian ini yaitu ingin diketahui apakah iklan layanan masyarakat terkait Masyarakat Ekonomi ASEAN dan Cultural Intelligence memiliki pengaruh terhadap minat berkarier mahasiswa untuk bekerja di negara-negara ASEAN lainnya. Mahasiswa yang dipilih sebagai responden penelitian ini adalah mahasiswa Universitas Trisakti program studi Akutansi. Program studi Akutansi ditetapkan sebagai sampel penelitian ini karena profesi akuntan adalah satu dari delapan profesi yang berpeluang paling tinggi untuk berpartisipasi dalam Masyarakat Ekonomi ASEAN. Universitas Trisakti juga merupakan salah satu pusat study ASEAN. Selain itu mahasiswa Universitas Trisakti juga dianggap memiliki latar belakang yang tepat untuk memiliki Cultural Intelligence yang diperlukan untuk menopang karier individu yang akan bekerja di luar negeri. 
Tujuan dilakukannya penelitian ini adalah:

1. Untuk mengungkap pengaruh antara iklan layanan masyarakat terkait Masyarakat Ekonomi ASEAN di Youtube terhadap minat berkarier mahasiswa untuk berkerja di luar negeri.

2. Untuk mengungkap pengaruh antara Cultural Intelligence terhadap minat berkarier mahasiswa untuk berkerja di luar negeri.

3. Untuk mengungkap pengaruh antara iklan layanan masyarakat terkait Masyarakat Ekonomi ASEAN di Youtube dan Cultural Interlligence terhadap minat berkarier mahasiswa untuk bekerja di luar negeri.

Adapula manfaat dari penelitian ini berupa:

1. Manfaat Akademis

Hasil penelitian ini diharapkan dapat bermanfaat bagi pihak-pihak yang tertarik untuk melakukan penelitian dengan variabel serupa dengan memberikan gambaran dan masukan untuk penelitian yang dapat dikembangkan lagi di masa yang akan datang.

2. Manfaat Praktis

Hasil penelitian ini diharapkan dapat memberikan suatu gambaran dan juga masukan bagi pihak yang tertarik untuk memiliki peluang berkarier di negara anggota ASEAN terkait dengan variabel penelitian. Hasil dari penelitian dapat menjadi masukan untuk Kementrian Ketenagakerjaan agar dapat mempengaruhi minat masyarakat Indonesia terutama mahasiswa untuk berpartisipasi dalam Masyarakat Ekonomi ASEAN.

\section{TINJAUAN PUSTAKA}

\subsection{Uses and Gratification}

Teori Uses \& Gratification pertama kali dikenalkan oleh Blumler dan Katz pada tahun 1974 sebagai teori yang berlawanan dengan teori peluru. (Nurudin, 2016, p.191) Teori ini berawal dari sudut pandang bahwa komunikasi (media massa) tidak mempunyai kekuatan untuk mempengaruhi khalayak. Teori ini menjelaskan bahwa khalayak menggunakan media massa berdasarkan motif-motif tertentu, sedangkan media berfungsi untuk memenuhi motif khalayak. Ketika motif terpenuhi maka kebutuhan khalayakpun terpenuhi. Saat hal itu terjadi, media yang mampu memenuhi kebutuhan khalayak disebut media yang efektif. (Kriyantono, 2008, p.206)

Pengguna media dianggap sebagai peranan yang aktif dalam proses komunikasi, dimana pengguna media mencari sumber media yang paling baik untuk memenuhi kebutuhannya. Teori ini menekankan pen- dekatan manusiawi dalam melihat media massa, dimana manusia mempunyai otonomi, wewenang untuk memperlakukan media. Teori ini juga menjelaskan bahwa konsumen media mempunyai kebebasan untuk memutuskan bagaimana (melalui media apa) mereka menggunakan media dan bagaimana media itu akan berdapak pada dirinya. Dapat dipahami pula interaksi individu dengan media melalui pemanfaatan media oleh individu tersebut (uses) dna kepuasaan yang diperoleh (gratification). Imbalan atau efek dalam teori ini dapat diterima saat itu juga (segera) atau tertunda. (Nurudin, 2016, p.192)

Kepuasan yang diperoleh khalayak dijelaskan dapat berupa hiburan, relaksasi, pelarian atau prestise sosial. Khalayak diasumsikan mengerti bahwa kesadaran akan persoalan umum sangat berharga dalam percakapan. Sebagian kelompok masyarakat juga menggunakan media untuk memperoleh informasi yang dapat membantu kehidupan sehari-hari mereka seperti mencari informasi mengenai mode, resep masakan, ramalan cuaca, maupun informasi bermanfaat lainnya. (Severin \& Tankard, 2011, p.354)

\subsection{Keterkaitan Uses \& Gratification dengan Teori Komunikasi Dunia Maya}

Berdasarkan hasil penelitian Greenberg dalam Severin \& Tankard (2011, p.454) tentang uses \& gratification yang diperoleh khalayak dari media massa adalah untuk mengembangkan beberapa kemungkinan motivasi pemakaian komputer. Komputer merupakan sumber utama khlayak untuk mempelajari apa yang sedang terjadi di dunia, untuk mencari hiburan, untuk bergembira, untuk relaksasi, untuk melupakan masalah, untuk menghilangkan kesepian, untuk mengisi waktu atau sebagai sebuah kebiasaan.

Sifat media yang paling penting bagi pengguna situssitus online adalah Kesiapan (dapat mengetahui sesuatu dengan segera) dan Stabilitas (dapat memperoleh berita kapan saja mereka inginkan adalah yang paling penting bagi pengguna situs-situs berita online. Menurut Severin \& Tankard (2011, p.454) sebagian besar pengguna internet adalah orang yang sudah dewasa. Ia menjelaskan bahwa kaum muda dewasa (usia 18-24) cenderung memanfaatkan internet untuk beragam tujuan, sedangkan pengguna dewasa tua (usia 35-54) cenderung menggunakan internet untuk memperoleh berita dan informasi.

Dengan menggunakan teori Uses \& Gratification ini maka ingin diketahui apakah iklan layanan masyarakat terkait Masyarakat Ekonomi ASEAN di Youtube mempunyai pengaruh terhadap minat berkarier 
mahasiswa untuk bekerja di luar negeri. Pada penelitian ini, sesuai dengan teori yang ada diketahui bahwa mahasiswa yang menonton ILM yang diunggah di Youtube dianggap sebagai sebuah interaksi individu dengan media melalui memanfaatan media tersebut (uses). Sehingga ingin diketahui apakah mahasiswa yang menyaksikan ILM yang diunggah di Youtube menerima kepuasan atau efek (gratification) untuk bekerja di luar negeri.

Istilah new media atau media baru pada umumnya merujuk pada media digital yang dimana media digital dipahami sebagai media yang interaktif dan mampu menggabungkan komunikasi dua arah dan melibatkan beberapa bentuk komputasi dengan "media lama" seperti telepon, radio dan televisi. Media lama diasumsikan untuk sebagian besar media massa, sedangkan media baru diasumsikan dengan media yang mengandalkan internet maupun website. (Logan, R. K, 2010, p.4) Kala ini Media Layanan Masyarakat dimana media swasta dalam negeri dan situs media digital terus bersaing untuk menjangkau publik yang lebih banyak. Situs media digital yang dimaksud diantaranya seperti buzzFeed, Huffington Post serta layanan video-on-demand seperti Netflix dan amazon Prime, maupun perantara digital besar seperti Google, Youtube dan situs jejaring sosial seperti Facebook dan Twitter. Sebagian besar organisasi layanan publik melihat peluang besar dalam distribusi media sosial terutama untuk menjangkau masyarakat yang berada di lokasi yang berbeda. (Sehl et al, 2016, p.10)

Pada penelitian ini, untuk mendukung variabel Iklan Layanan Masyarakat, digunakan juga variabel Cultural Intelligence yang dipahami sebagai kecerdasan kultural. Cultural Intelligence merupakan kemampuan untuk berperilaku secara efektif dalam konteks antar budaya. Kecerdasan kultural dapat merujuk pada kemampuan individu, tim atau sebuah perusahaan. Konteks antar budaya yang dimaksud meliputi keanekaragaman budaya termasuk keragaman berkebangsaan atau nilai-nilai budaya, serta keragaman yang berdasarkan subkultur seperti profesi, usia, jenis kelamin, dan agama. Cultural Intelligence dianggap penting bagi seorang individu maupun organisasi yang mengakui pentingnya nilai budaya sebagai penghubung kesuksesan pribadi maupun organisasi dikarenakan dunia yang memiliki beragam budaya. (Dyne, 2017, p.2)

Cultural Intelligence bermanfaat untuk program yang mengunggulkan pengalaman internasional maupun program yang mengirimkan siswa ke berbagai tempat kerja yang beragam secara budaya. Ide kecerdasan kultural berakar pada kecerdasan lain, seperti kecerdasan emosional dan sosial, namun kemudian disadari bahwa untuk berada dalam lingkungan antar budaya diperlukan dimensi kecerdasan lain yaitu kecerdasan kultural. (Norah, 2011, p.7)

Memperlajari budaya lain berkaitan dengan pemahaman orang-orang dari latar belakang budaya atau budaya yang berbeda dari orang-orang sehingga individu mampu mambuka wawasan dan membangun sikap. Sehingga apabila dihadapi dengan sikap yang tidak sewajarnya oleh warga negara asing yang memiliki latar belakang budaya yang berbeda, individu dapat memberikan pemahaman dan toleransi. Sebaliknya apabila seseorang yang memiliki latar belakang budaya yang berbeda salah menafsirkan pola budaya yang kompleks, maka akan timbul kesalahpahaman lintas budaya. (Pujiyanti \& Zuliani, 2014, p.1)

Individu yang memiliki dasar Cultural Intelligence diharapkan mampu untuk berperilaku dan berinteraksi secara efektif dengan orang lain yang memiliki latar belakang budaya yang berbeda. Maka dari itu pada penelitian ini digunakan Cultural Intelligence sebagai variabel penelitian untuk mengukur minat berkarier mahasiswa untuk bekerja di luar negeri. Mahasiswa yang memiliki Cultural Intelligence yang cukup mengenai negara-negara anggota ASEAN diharapkan mampu meningkatkan minat berkarier mereka karena kecerdasan budaya itu sendiri adalah ilmu dasar yang paling bermanfaat saat mereka bekerja di luar negeri.

Lain halnya dengan mahasiswa yang tidak memiliki Cultural Intelligence yang cukup, baik itu karena tidak cukup handal dalam berbahasa asing atau belum pernah mengunjungi salah satu negara anggota ASEAN, tentunya respon yang diberikan akan berbeda karena ilmu kecerdasan budaya yang ia miliki tidak cukup kuat. Apabila keahlian individu baik namun kecerdasan kultural yang dimiliki tidak cukup, maka individu akan kesuliltan dalam beradaptasi dan berinteraksi dengan baik dalam pekerjaan maupun dalam kehidupan sehari-hari. Maka dari itu, individu yang tidak memiliki Cultural Intelligence dianggap tidak cocok untuk menguji konsep dalam penelitian ini.

\section{METODE PENELITIAN}

Metodologi pada penelitian ini menggunakan metode penelitian kuantitatif. Dalam penelitian ini populasi adalah mahasiswa Universitas Trisakti fakultas Ekonomi dan Bisnis. Fakultas Ekonomi dan Bisnis Universitas Trisakti menaungi program studi Akuntansi, 
Management dan Ekonomi Pembangunan. Mahasiwa Universitas Trisakti dianggap memiliki latar belakang yang tepat untuk memiliki Cultural Intelligence yang diperlukan untuk menopang karier individu apabila bekerja di luar negeri, seperti ilmu atau informasi yang diperoleh, lingkungan pergaulan, pemanfaatan teknologi dan sosial media serta faktor ekonomi keluarga. Maka dari itu mahasiswa dirasa pilihan yang tepat sebagai populasi dalam penelitian ini.

Sebagai wakil dari semua unit yang ada dalam populasi, sampel yang digunakan dalam penelitian ini adalah mahasiswa dari Universitas Trisakti program studi Akuntansi tahun ajaran akhir yang berjumlah 534. Program studi Akuntansi ditetapkan sebagai populasi penelitian ini karena profesi akuntan adalah salah satu dari delapan profesi yang berpeluang paling tinggi untuk berpartisipasi dalam Masyarakat Ekonomi ASEAN. Untuk menentukan jumlah populasi penelitian, digunakan rumus slovin yang dijabarkan sebagai berikut:

Keterangan:

$$
n=\frac{N}{N \cdot e^{2}+1}
$$

$\mathrm{n}=$ Jumlah Sampel

$\mathrm{N}=$ Jumlah Populasi

$\mathrm{e}=$ error level (tingkat kesalahan) umumnya digunakan $1 \%$ atau 0,01 ; atau 0,05 ; dan $10 \%$ atau 0,1. (Sugiyono, 2013, p.201)

Untuk mendapatkan sampel (n), maka maka dilakukan perhitungan berdasarkan rumus slovin yang dijabarkan sebagai berikut:

$$
\begin{aligned}
& \mathrm{n}=\frac{534}{534 \cdot(0 \cdot 1 \cdot 0 \cdot 1)+1} \\
& \mathrm{n}=\frac{534}{6.34} \\
& \mathrm{n}=845
\end{aligned}
$$

Berdasarkan perhitungan di atas, ukuran sampel minimal yang digunakan dalam penelitian ini adalah 85 orang mahasiswa. Maka dari itu sampel sebanyak 90 orang mahasiswa program studi akuntansi yang sudah menyaksikan iklan layanan masyarakat terkait Masyarakat Ekonomi ASEAN di Youtube ditetapkan untuk penelitian ini. Teknik penarikan sampel yang digunakan adalah teknik penarikan sampel Purposive Sampling dimana penarikan sampel dilakukan atas seleksi kriteria-kriteria tertentu yang sudah ditetapkan berdasarkan tujuan penelitian. (Kriyantono, 2008, p. 156)
Maka dari itu, ada beberapa kriteria yang diajukan diantaranya seperti berikut:

1. Responden adalah mahasiswa yang terdaftar dalam program studi Akuntansi fakultas Ekonomi dan Bisnis Universitas Trisakti tahun ajaran akhir.

2. Responden sudah menonton iklan layanan masyarakat terkait Masyarakat Ekonomi ASEAN di Youtube, karena dirasa dapat memberikan informasi yang diinginkan sesuai dengan permasalahan penelitian.

Teknik pengumpulan data yang digunakan sebagai data primer ialah kuesioner dengan pertanyaan tertutup. Data sekunder yang digunakan untuk melengkapi serta mendukung data primer diperoleh dari buku, artikel jurnal, internet dan penelitian sebelumnya yang berkaitan dengan penelitian ini. Dalam penelitian ini analisis data yang digunakan ialah pendekatan Partial Least Square (PLS). Menurut Ghozali (2015, p.30) PLS adalah model persamaan Structural Equation Modeling (SEM) yang berbasis komponen atau varian. PLS merupakan metode analisis yang powerful, karena tidak didasarkan pada banyak asumsi. PLS juga dapat digunakan untuk menjelaskan ada tidaknya hubungan antar variabel laten. PLS dapat sekaligus menganalisis konstruk yang dibentuk dengan indikator reflektif dan formatif. (Ghozali, 2015, p.31)

\section{HASIL DAN PEMBAHASAN}

H1: Terdapat pengaruh signifikan antara Iklan layanan masyarakat terkait Masyarakat Ekonomi ASEAN di Youtube terhadap minat berkarier mahasiswa untuk bekerja di luar negeri.

Berdasarkan tabel pengujian hipotesis diatas dapat diketahui bahwa nilai signifikansi t hitung pengaruh Iklan layanan masyarakat terkait Masyarakat Ekonomi ASEAN di Youtube terhadap Minat berkarier mahasiswa untuk bekerja di luar negeri sebesar $0.334<1,97$ dengan nilai $\mathrm{p}$ values 0.738 . Hal ini dapat diartikan bahwa Iklan layanan Masyarakat terkait Masyarakat Ekonomi ASEAN di Youtube tidak berpengaruh terhadap Minat berkarier mahasiswa untuk bekerja di luar negeri, sehingga hipotesis yang menyatakan Iklan layanan Masyarakat terkait Masyarakat Ekonomi ASEAN di Youtube berpengaruh positif terhadap Minat berkarier mahasiswa untuk bekerja di luar negeri ditolak.

H2: Terdapat pengaruh signifikan antara Cultural Intelligence terhadap minat berkarier mahasiswa untuk bekerja di luar negeri. 
Berdasarkan tabel pengujian hipotesis di atas dapat diketahui bahwa nilai signifikansi t hitung pengaruh Cultural Intelligence terhadap minat berkarier mahasiswa untuk bekerja di luar negeri sebesar 3.219 $>1,97$ dengan nilai $\mathrm{p}$ values 0.001 . Hal ini dapat diartikan bahwa Cultural Intelligence berpengaruh positif terhadap minat berkarier mahasiswa untuk bekerja di luar negeri. Sehingga hipotesis yang menyatakan Cultural Intelligence berpengaruh positif terhadap Minat berkarier mahasiswa untuk bekerja di luar negeri diterima. Hal ini dipengaruhi oleh tingkat kecerdasan kultural mengenai negara -negara anggota ASEAN yang miliki mahasiswa terbukti cukup kuat untuk menimbulkan minat berkarier mereka untuk bekerja di luar negeri. Hal ini dapat terjadi dikarenakan iklan membutuhkan proses untuk dapat membentuk minat dari seseorang.

H3: Terdapat pengaruh signifikan antara Iklan layanan masyarakat terkait Masyarakat Ekonomi ASEAN di Youtube dan Cultural Intelligence terhadap minat berkarier mahasiswa untuk bekerja di luar negeri.

Berdasarkan pengujian hipotesis diatas dapat diketahui bahwa nilai signifikansi f hitung pengaruh Iklan layanan masyarakat terkait Masyarakat Ekonomi ASEAN di Youtube dan Cultural Intelligence terhadap Minat berkarier mahasiswa untuk bekerja di luar negeri sebesar $83.918>1,97$ dengan nilai $p$ values 0.000 . Dapat dilihat juga bahwa hasil $R$ Square bahwa kontribusi Iklan Layanan Masyarakat terkait Masyarakat Ekonomi ASEAN di Youtube dan Cultural Intelligence terhadap Minat sebesar 66\%. Sehingga dapat dilihat bahwa Iklan layanan Masyarakat terkait Masyarakat Ekonomi ASEAN di Youtube dan Cultural Intelligence berdampak kuat dalam mempengaruhi minat berkarier mahasiswa untuk bekerja di luar negeri.

Sesuai dengan penjelasan Logan (2010, p.4), istilah new media atau media baru pada umumnya merujuk pada media digital yang dimana media digital dipahami sebagai media yang interaktif dan mampu menggabungkan komunikasi dua arah dan melibatkan beberapa bentuk komputasi dengan "media lama" seperti telepon, radio dan televisi. Keterkaitan antara new media dengan penelitian ini adalah dimana hubungan internasional saat ini bisa memanfaatkan media baru ini untuk melakukan diplomasi. Penelitian ini merupakan salah satu contoh pemanfaatan new media dalam bidang hubungan internasional dengan menggunakan Youtube sebagai sarana untuk memperkenalkan dunia internasional kepada masayarakat.
Teori Uses and Gratification menjelaskan bahwa khalayak menggunakan media massa berdasarkan motif-motif tertentu, sedangkan media berfungsi untuk memenuhi motif khalayak. Ketika motif terpenuhi maka kebutuhan khalayakpun terpenuhi. Saat hal itu terjadi, media yang mampu memenuhi kebutuhan khalayak disebut media yang efektif. (Kriyantono, 2008, p.206). Keterkaitan antara Uses and Gratification dengan penelitian ini adalah dimana dengan penggunaan Youtube sebagai media, menunjukkan bahwa pihak-pihak yang menjadi komunikator mengetahui bahwa komunikan membutuhkan berita dan mencari berita melalui youtube. Penelitian ini akan menjelaskan sejauh mana komunikator telah berhasil menggunakan Youtube sebagai media untuk memenuhi kebutuhan mahasiswa dan mendorong mahasiwa untuk bekerja di luar negeri.

\section{KESIMPULAN}

Berdasarkan hasil analisis, maka diperoleh kesimpulan sebagai berikut:

1. Iklan layanan masyarakat terkait Masyarakat Ekonomi ASEAN di Youtube (X1) tidak memiliki memiliki pengaruh terhadap minat berkarier mahasiswa untuk bekerja di luar negeri (Y1).

2. Cultural Intelligence (X2) yang dimiliki mahasiswa memiliki pengaruh terhadap minat berkarier mahasiswa untuk bekerja di luar negeri (Y1)

3. Kontribusi dari klan layanan masyarakat terkait Masyarakat Ekonomi ASEAN di Youtube (X1) dan Cultural Intelligence (X2) terhadap minat berkarier mahasiswa untuk bekerja di luar negeri (Y1) adalah sebesar 66\% dan 34\% sisanya dipengaruhi oleh faktor lain. Secara keseluruhan dapat disimpulkan bahwa terdapat peningkatan minat bekarier mahasiswa untuk bekerja di luar negeri yang dipengaruhi oleh Iklan Layanan Masyarakat terkait Masyarakat Ekonomi ASEAN di Youtube dan Cultural Intelligence. Dari penelitian ini dapat diketahui pula bahwa mahasiswa masih banyak yang belum sepenuhnya memahami Masyarakat Ekonomi ASEAN dan apa saja yang harus mereka persiapkan agar mampu berpartisipasi di dalamnya.

Berdasarkan hasil penelitian, berikut adalah rekomendasi berupa saran untuk penelitian dengan topik serupa di waktu yang akan datang:

1. Minat berkarier mahasiswa untuk bekerja di luar negeri dipengaruhi sebesar $66 \%$ oleh iklan Layanan Masyarakat terkait Masyarakat Ekonomi ASEAN di Youtube dan Cultural Intelligence dan 34\% dipengaruhi oleh faktor lain yang tidak dibahas dalam penelitian ini. Oleh karena itu, selanjutnya dalam penelitian serupa baiknya dilakukan penelitian faktor-faktor lain berupa 
efektivitas iklan, penggunaan animasi pada iklan atau penggunakan musik pada iklan.

2. Dalam penelitian ini tidak dibahas bagaimana analisis iklan layanan masyarakat terkait Masyarakat Ekonomi ASEAN di Youtube dalam meningkatkan minat berkarier mahasiswa untuk bekerja di luar negeri. Maka dari itu, selanjutnya dapat dilakukan penelitian menggunakan topik serupa namun dengan metode penelitian yang berbeda yaitu Kualitatif.

\section{DAFTAR PUSTAKA}

Dit. Kerja Sama Ekonomi ASEAN. (2015, Desember). Masyarakat ASEAN: Maju Bersama Masyarakat ASEAN, Edisi 10. ISSN 24601683. Diperoleh dari: https://www.kemlu.go.id/ Majalah/ASEAN\%20Edisi\%2010.pdf.

Dyne, V. L., Ang, S., and Tan, M., L. (2017). Handbook of Cultural Intelligence - Management Oxford Bibliographies. New York: Sharpe.

Friedrich Elbert Stiftung. (2014, Desember 16). Video masyarakat ekonomi ASEAN: Pertumbuhan ekonomi yang menguntungkan semua pekerja [Video file]. Diperoleh dari https://www.youtube.com/watch?v=0RiluuVto3k

Ghozali, Imam dan Latan (2015). Partial Least Squares: Konsep, Teknik dan Aplikasi Menggunakan SmartPLS 3.0, Edisi 2. Semarang: Badan Penerbit Universitas Diponegoro.

Kriyantono, R. (2008). Teknik Praktis riset Komunikasi. Jakarta: Kencana Prenada Media.
Logan, R. K. (2010). Understanding New Media Extending Marshall McLuhan. New York: Peter Lang Publishing.

Masyarakat Ekonomi ASEAN (MEA). 2015. [n.d]. Diperoleh pada 29 Januari 2018, dari website Kementrian Luar Negeri Republik Indonesia: https://www.kemlu.go.id/id/kebijakan/asean/Pag es/Masyarakat-Ekonomi-ASEAN-(MEA).aspx.

Norah, M. (2011). Cultural Intelligence: Developing Students Who Can Act Local and Think Global. Wace 17th World Conference of Cooperative \& Work Integrated Education Drexel University, Philadelphia. ISSN 2152-0518. Diperoleh dari http://www.waceinc.org/philly2011/conference proceedings/Refereed\%20Papers/Canada/NOR AHM 1.PDF.

Nurudin. (2016). Ilmu Komunikasi Ilmiah dan Populer. Jakarta: Raja Grafindo

Pujiyanto. (2013). Iklan Layanan Masyarakat. Yogyakarta (ID): Andi Offset.

Sehl, A., Cornia, A., and Nielsen, R. K. (n.d). Public Service News and Digital Project 2016. Published by the Reuters Institute for the Study of Journalism with the support of Google and the Digital News Initiative. Diperoleh dari http://www.waceinc.org/philly2011/conference_ proceedings/Refereed\%20Papers/Canada/NOR AHM 1.PDF.

Severin, W., and Tankard, J. (2011). Comminication Theories: Origins, Methods, and Uses in the Mass Media. New York: Pearson.

Sugiyono. (2013). Metode Penelitian Pendidikan Pendekatan Kuantitatif, Kualitatif, dan R\&D. Bandung: Alfabeta. 